\section{Introducing the Journal of Democracy}

On a bright spring day before the brutal crackdown in Beijing's Tiananmen Square, students from across China were sharing in the exuberance of the nascent democratic movement sweeping the country. Largely unorganized and lacking a clearly defined strategy, the students nevertheless displayed remarkable courage and determination, prompting one student to say, "I don't know what democracy is, but we need more of it."

In fact, however, the student demonstrators and hunger-strikers-and hundreds of thousands of Chinese intellectuals, workers and bystanders who rallied to their cause-shared a broad vision of democracy. Although most of them had known nothing throughout their lives but Marxist-Leninist rule, they understood democracy in terms recognizable to peoples around the world: freedom of speech and association, representative and accountable government, equal protection and due process under the impartial rule of law.

What China's young democrats did not have was a full understanding of how democracy comes about or of the problems and pitfalls that may abort its birth and mar its functioning. Around the world, democratic activists, movements, and organizations often are not aware of similar efforts undertaken by democratic forces in other countries, much less the ideas, tactics and organizational strategies successfully being employed in mobilizations for democracy. In this country, too, scholars, policy-makers and the concerned public lack an adequate understanding of the struggles now unfolding in every part of the globe to obtain and institutionalize democratic governments.

With a view toward filling this gap and addressing the growing international demand for the exchange of ideas and experiences regarding democracy, the National Endowment for Democracy (NED) is helping to launch a new quarterly publication, the Journal of Democracy. It will begin publishing in January 1990 under the editorship of Marc F. Plattner, now Director of Program at NED, and Larry Diamond, Senior Research Fellow at the Hoover Institution, Stanford University.

The editors will determine the journal's editorial policy in consultation with an independent editorial board composed of leading political scientists and intellectuals. They are: Chinua Achebe (University of Nigeria, Nsukka), Shaul Bakhash (George Mason University), Naomi Chazan (Hebrew University of Jerusalem), Charles Fairbanks (SAIS, Johns Hopkins University), Harry Harding (The Brookings Institution), Samuel P. Huntington (Harvard University), Atul Kohli (Princeton University), Leszek Kolakowski (Oxford University and the University of Chicago), Leopold Labedz (editor of Survey), Liang Heng (editor, The Chinese Intellectual), Juan Linz (Yale University), Seymour Martin Lipset (Hoover Institution, Stanford University), Joshua Muravchik (American Enterprise Institute), Ergun Ozbudun (University of Ankara), Octavio Paz (director of the Mexican journal Vuelta), Susan Purcell (the Americas Society), Peter Reddaway (George Washington University), Alfred Stepan (Columbia University), Arturo Valenzuela (Georgetown University), and Ernest J. Wilson III (University of Michigan).

Drawing on the rich and varied expertise of this distinguished editorial board, and on the profusion of democratic scholarship and activism in recent years, the Journal of Democracy will survey and analyze democratic developments worldwide. It will report on and assess the prospects and strategies for democratic transitions in China, the Soviet Union and Eastern Europe, Latin America, Asia, Africa and the Middle East. It will analyze efforts to deepen and institutionalize democracy, and the challenges facing troubled democracies. It will cover events-elections, coups, transitions, crises-and put them in perspective. It will invite spirited debate among competing democratic viewpoints.

The journal of Democracy will be a leading international forum of scholarship on democracy. It will seek to advance theoretical and comparative understanding of the political, social, economic, cultural, and 
international factors that promote democracy. But it will do more as well. Reports from the field will offer first-hand accounts of democratic movements and organizations, written by the civic group leaders, activists, journalists and trade unionists who are on the front lines of the struggle. Eminent intellectuals will reflect on the principles and prospects of democracy. Interviews will be conducted with leading democratic figures. And the journal regularly will publish key documents on democracy, information on recent and upcoming elections, reports on important meetings and conferences, and reviews of topical books.
The Journal of Democracy will be more than just another academic quarterly. It seeks to help unify and enrich the growing intellectual and political movements for democracy worldwide.

Subscription rates for the journal of Democracy are \$24/year for individuals and $\$ 45 /$ year for institutions. Subscription orders should be sent to Journal of Democracy, Subscription Services, P.O. Box 3000, Dept. JD, Denville, NJ 07834.

For further information, contact Peter Pavilionis, Journal of Democracy, II0I Fifteenth Street, NW, Suite 200, Washington, D.C. 20005, or call (202) 293-9072. 